\title{
Augusto Monterroso's short story collections: More than stories in a box
}

\section{ABSTRACT}

1.

2.

3.

4.

5.

6.

7.

8.

9.

10.

11.

12.

13.

14.

15.

16.

17.

18.

19.
This article considers the work of the Guatemalan author Augusto Monterroso as it offers an interesting perspective on the theory and practice of the short story collection. In his essays, Monterroso often comments on the formal features of the short story, its relation to the novel and its marginal status in literary criticism. In addition, he frequently refers to the work of other short story writers. About his own books, Monterroso has said that they are 'simple deposits' or 'boxes', because they include different kinds of texts: short stories and essays, but also translations of the work of other authors. Examples in case are the collections Movimiento Perpetuo (1972), translated as Perpetual Motion (1995), and La palabra mágica (1983). In this article I analyse Perpetual Motion with a view to determining the precise organization and structure of the collection. Using the concepts of homogeneity and heterogeneity, proposed by theorists such as René Audet and Robert Luscher, I try to discern a pattern in the disparate texts and issues of Perpetual Motion.

\section{INTRODUCTION}

While the short story has long been an established object of critical enquiry in Spanish and Latin American literary criticism, ${ }^{1}$ the short story collection, on the contrary, received little or no critical attention in the twentieth century.

\section{KEYWORDS}

short story

essay

fable

intertextuality

brevity

Guatemalan literature 
1. See the studies of Seymour Menton (1979) Carmen de Mora (1995) or Enrique Pupo-Walker (1995).

2. Unless otherwise indicated, all translations from Spanish to English are my own

3. Only three of Monterroso's works have been translated into English: Obras completas (y otros cuentos) (1959) and Movimiento Perpetuo (1972) are both included in Complete Works and Other Stories (1995); La Oveja Negra y demás fábulas ([1969] 1991) was translated as The Black Sheep and Other Fables in 1971. With the exception of the quotations from these two works, therefore all Spanish to English translations from Monterroso's work are my own.
In 2000 María Luisa Antonaya still commented on the critical ambiguity surrounding the collection and on the lack of recognition of the ciclo de cuentos, the short story cycle, as a separate genre. Such collections, she argued, were in fact mostly classified as 'experimental or fragmented novel[s]' (María Luisa Antonaya 2000: 433). ${ }^{2}$ Fortunately, this situation has changed in recent years and the short story cycle has become a topic of interest among both writers and critics of Latin American literature. In an interesting article from 2002, the Argentinian writer Rodrigo Fresán makes a distinction between 'a book with stories' and 'a book of stories' (2002). In 'a book with stories', he argues, the author collects texts he has previously published in journals or anthologies. 'A book of stories', to the contrary, is for Fresán 'like a strange but attractive animal'. Its structure, he calls 'perfectly assembled and harmonious'; a 'perfect and indestructible whole'. In 2006, Pablo Brescia and Evelia Romano edited an important critical study on the short story cycle in the Latin American tradition: El ojo en el caleidoscopio/The Eye in the Kaleidoscope. The nineteen essays in this collection discuss theoretical aspects, give a historical view of some national literatures or analyse specific cases. In their introduction to the essay collection, the editors give an overview of the different definitions of and observations on the short story cycle in the Anglo-American tradition and they compare it to the terms that have been put forward in Latin American criticism. Enrique Anderson Imbert (1979), for instance, refers to the short story cycle as cuentos enlazados, interlinked stories. Brescia and Romano, on the contrary, prefer the term textos integrados or integrated texts. They specifically opt for the general term 'texts', because it can refer to essays, stories or even poems. More recently, Salvador Mercado Rodríguez (2012) has studied different forms of hybrid texts, on a continuum between the short story collection and the novel, in contemporary Puerto Rican literature. He argues that these authors themselves play with these hybrid forms in various ways, as can be seen from the plethora of terms they propose for their work. Novela contada, novela cuentada, novela cuenteada and cuentos novelados are all terms that playfully refer to both genres, the novel (novela) and the short story (cuento). Yet another term, novela compuesta, can be translated as composite novel.

In the Anglo-American tradition, to the contrary, the term short story cycle seems to have won out over rivalling terms, such as short story sequence, short story composite and composite novel. Still, as in Latin American criticism, scholars also take care to delineate the short story cycle against neighbouring genres. In The Contemporary American Short-Story Cycle, James Nagel argues:

The short story cycle thus has a long and complex history and a diversity of implementation so broad as to escape limited definition. To some extent its central components are best described through critical triangulation: a cycle is less unified than a novel but has much greater coherence and thematic integrity than a mere collection of unrelated stories.

(2001: 17)

In this article, I will try to further clarify these and related concerns by means of a study of Augusto Monterroso's collection Movimiento Perpetuo (1972), which translated as Perpetual Motion in 1995. ${ }^{3}$ Monterroso was born in 1921 in Honduras and lived in political exile in Mexico from 1944 until his death in 2003. I will analyse the structure and organization of Perpetual Motion
1. 2. 3. 4. 5. 6. 7. 8. 9. 10. 11. 12. 13. 14. 15. 16. 17. 18. 19. 20. 21. 22. 23. 24. 25. 26. 27. 28. 29. 30. 31. 32. 33. 34. 35. 36. 37. 38. 
against the background of recent theories of the short story collection and short story cycle. Particularly useful will be René Audet's description of the oppositional forces of homogeneity and heterogeneity at work in the short story cycle (2000: 36) as well as Robert Luscher's argument that the realization of the short story cycle, or sequence as he calls it, depends on the reader's identification of recurring patterns and concerns:

As in a musical sequence, the story sequence repeats and progressively develops themes and motifs over the course of the work, its unity derives from a perception of both the successive ordering and recurrent patterns, which together provide the continuity of the reading experience.

(1989: 149)

A central question in this article, therefore, is to what extent such patterns can be found in Perpetual Motion. First, however, I will analyse Monterroso's own views on the genre of the short story.

\section{THE SHORT STORY: ALWAYS A PROBLEMATIC GENRE}

In his essays, Monterroso has often commented on the formal features of the short story, its relation to the novel and its marginal status in literary criticism. In a diary fragment, 'Los cuentos cortos, cortos'/'Short, short stories' ([1987] 1998a: 93-94) and in the essay 'Breve, brevísimo'/'Short, shorter' (2004: 97-115), Monterroso tries to find an answer to the fundamental question: What is a short story? In an interview with Marco Antonio Campos from 1977, Monterroso explains the difference between the novel and the short story as follows: 'The short story must have some freedom, but within certain laws or limits. [...] One such law could be that the story is neither a novel, nor a poem nor an essay, and that at the same time it is an essay, a novel and a poem, as long as it is that mysterious thing called story' ([1981] 1989: 60). Monterroso then refers to Borges in order to better understand and examine the differences between the novel and the short story. Monterroso does not agree with Borges, who considers the novel as a succession of stories. That may be the case for some novels, such as Don Quixote, but from the nineteenth century onwards, Monterroso argues, the novel is required to form a whole ([1981] 1989: 61).

Monterroso has often himself been very sensitive about the marginal status of the short story: "The public wants novels", is what editors usually say to storywriters, poets and essayists when they want to get rid of them' (1998b: 74). Even so, in the text 'El árbol'/'The tree', he ponders:

What do we pretend when we approach these new forms of the story, short or very short? How to confront this [...] apathy of readers and editors towards this genre that over the years has persisted stubbornly next to the other great genres that seem to constantly overshadow and nullify it? In different ways: transforming it, changing the sense, sometimes reducing it to the absurd, or even disguising it: as a poem, a meditation, a review, an essay, all of this, without abandoning his first objective - to tell a story - that makes it richer and excites the imagination and emotions of the reader.

(1998b: 55) 
Among the many references to other authors in Monterroso's work, short story writers stand out: Joyce, Darío, Borges, Kafka, Cortázar, Poe, Rulfo, Quiroga, to name but a few. In his essays, Monterroso analyses the work of other short story writers from different perspectives. On a few occasions, he highlights the unity of the collection and the elements that link the stories. In an essay on the work of the Uruguayan writer Horacio Quiroga, he notes: 'Except in a few instances, his stories are united by a common thread: most of them deal with fatality and ungratefulness. In all of them, there is also a profound human sense, a greatness' (Monterroso [1983] 1985: 14). Monterroso emphasizes the internal unity of Quiroga's short story collection and is impressed by the fundamental topics that link the stories at a thematic level. Something similar can be seen in the way Monterroso talks about Rulfo's work - his two novels, Pedro Páramo (1955) and El gallo de oro/The Golden Cockerel (1980), and his only short story collection, El llano en llamas/The Burning Plain (1953) - in terms of an overarching whole. He considers Rulfo's characters as though they were only one character: 'a phantasm that wanders along the whole work of Rulfo, under the form of wind, dust, desolation and sadness' (Monterroso 2004: 81). A third writer Monterroso is interested in is Cortázar. He comments in particular on Cortázar's short story collection, Historias de cronopios y de famas (1962), translated into English as Cronopios and Famas (1969). It is obvious for the reader that the unity of these stories is established through their surreal characters: The 'famas' represent the Argentinian upper class, the bourgeoisie from the 1950s and 1960s; the 'cronopios' can be seen as the middle class who wanted to imitate the 'famas' but decline into mediocrity. Monterroso focuses on these strange characters in a diary fragment about the commotion caused by Cortázar's work in the sixties: 'You could see how politicians and even economists were fascinated by what they saw in these beings of a new mythology [...] and they wanted to be like cronopios, they did not want to be solemn. Nonetheless, the only thing they achieved was to be ridiculous' ([1987] 1998a: 30). Again, this collection by Cortázar is seen by Monterroso as a whole.

In his comments on short fiction in general, Monterroso often emphasizes the strength and power of their characters. For Monterroso, many of the most memorable characters in literature belong to short stories rather than to novels: Poe's Auguste Dupin, Melville's Bartleby, Mann's Tobias Mindernickel, Turber's Walter Mitty - 'they will be remembered [...] for a longer time than all the characters of Hemingway's novels put together' ([1981] 1989: 61). Monterroso also edited an anthology of short stories based on the rather unusual concept of sad stories, Antología del cuento tristelAnthology of Sad Stories (1997), which includes 'Bartleby' and 'Tobias Mindernickel'.

When discussing Monterroso's views on short fiction, we cannot neglect to mention Monterroso's most famous story, 'The dinosaur'. It has often been discussed by literary critics as well as by other writers, because it is considered one of the shortest stories of western literature. This story of only seven words reads as follows: 'Cuando despertó, el dinosaurio todavía estaba allí/'When he awoke, the dinosaur was still there' (Monterroso [1959] 1990: 71, 1995: 42). Critics have referred to it as, amongst others, a short story, an anti-story, a mini-text, a micro-text, a mini-story, a fragment, a charade, a fable, a poem, an epigram, and a novel. This plethora of terms highlights not only the dissension among critics, but also the originality of the story and the fact that it escapes easy classification. All labels can indeed be valid for 'The dinosaur', be it in different ways.

1. 2. 3. 4. 5. 6. 7. 8. 9. 10. 11. 12. 13. 14. 15. 16. 17. 18. 19. 20. 21. 22. 23. 24. 25. 26. 27. 28. 29. 30. 31. 32. 33. 34. 35. 36. 37. 38. 39. 40. 41. 42. 43. 44. 45. 46. 47. 48. 49. 50. 51. 52. 
The suggestion that 'The dinosaur' is a novel comes in fact from Monterroso himself ([1981] 1989: 43, 2004: 113). In Literatura y vida/Literature and Life (2004) he explains that he took some scissors and got the story as a result. Yet, the popularity and fame of this story has also led to a mistaken idea of Monterroso's oeuvre. The author has commented, '[b]ecause of the dimensions and the festive character of this story, the public and the critics think I only write short stories that are also humoristic' (Monterroso 2004: 32). The idea that 'The dinosaur' is a novel is not simply a joke, but rather the reaction to a conceptual dilemma, as we can see in the essay 'Brevity' in Perpetual Motion. In this article the short story writer expresses the desire to write 'long texts, interminably long texts'. He dreams of writing novels; yet he cannot be a novelist because something superhuman prevents it. The short story writer is restrained by the semicolon or the period: "That period, which at this very moment has been imposed upon me by something stronger than myself, something I both respect and despise' (Monterroso 1995: 151). The tension between the novel and the short story has also been remarked on by Gerardo Mario Goloboff: "The dinosaur" on his own poses more questions to the reader than one of those pacific novels where everything is directed, oozed, and resolved, without alteration, surprises, or efforts' (1983: 186).

\section{NO UNITY, JUST A BOX}

Monterroso calls his books 'boxes', in which he can bring together different texts: short stories and essays, but also translated texts. In an interview from 1977, he explains the structure of Perpetual Motion as follows:

Books are simple deposits. They are like boxes. In a book one can put a novel or several stories, several poems and essays. One has something and just puts it into a book. For this book [Perpetual Motion] I had several texts available which I could put together and that's it, one just has to be careful not to put in too much trash [...]. On the other hand, pretending that a book must follow a straight line is an idea that doesn't fit in our times anymore.

([1981] 1989: 58)

The image of the box recalls B. S. Johnson's The Unfortunates, an experimental 'book-in-a-box', published in 1969, in which the loose chapters could be read in any order. The metaphor of the box also clearly reflects the idea of chaos, fragmentation and the lack of order: key-concepts in Monterroso's oeuvre. In another interview from the 1970s, he says about Perpetual Motion: 'It is a miscellaneous book: I did not want to make this book from the beginning. The book was made little by little with short essays and stories of different kinds. [...] Like my other books, I hope it does not have any unity' ([1981] 1989: 29). Yet, this last remark seems to clash with one of Monterroso's other books, $\mathrm{La}$ Oveja Negra y demás fábulas/The Black Sheep and Other Fables ([1969] 1991), which is clearly unified by the genre of the fable. Monterroso says about this:

I have never had the intention to write a book; the most I come up with is a short story, an essay, something short. Maybe the only occasion that I had the intention to make a book, with a certain generic unity, was with the fables. [...] For the first time, when I had about ten fables, I realized I could make a book in this way. So I wrote another ten. While 
I was writing them I was terrified by the idea that I had to write twice as 1 . much, but I continued, motivated by the idea, yes, to complete a book.

When questioned about the unity of Lo demás es silencio/The Rest is Silence (1978) - a book usually classified as a novel or an apocryphal biography, but which can also be seen as a collection of stories or a series of fragments Monterroso replies: 'This book has an internal diversity and an external unity, although I don't know exactly what that means. Maybe this is because I have used very different styles. The unity probably is due to the fact that the book deals with the same character' ([1981] 1989: 30). It is remarkable that after this explanation Monterroso suddenly asks the interviewer, 'Can we change the subject?' ([1981] 1989: 30). Questions about unity, whether internal or external, clearly make him uncomfortable.

Finally, his last book, Literatura y vida, contains a fascinating and rather long essay, entitled: 'Mi primer libro'/'My first book' (Monterroso 2004: 21-49). In this text, Monterroso explains in detail how his first book, Obras completas (y otros cuentos)/Complete Works and Other Stories ([1959] 1990) was composed. Typically, he presents the whole history from a very humble and modest perspective: he just collected some of his stories 'to please a friend' and 'to keep his job' (Monterroso 2004: 49). Henrique González Casanova, his employer at that moment, urged him to publish them. Monterroso did not see himself as a writer and was even afraid to become one (2004: 31). On the other hand, this article gives us an amazing inside view into the process of making the book: it tells about the 'story' behind the stories, some with a basis in reality, others purely fictional. It also shows how Monterroso selected those stories he considered the best out of all the stories he had previously published in reviews and journals (2004: 35). As a result, this collection contains stories written over a period of twelve years ([1981] 1989: 25).

In all, it may be clear that the unity - or lack of unity - of a given book is a matter of great concern for Monterroso. His sometimes contradictory statements on the topic suggest his ambivalent wavering between two poles: on the one hand, he knows that every book requires a certain unity or coherence; on the other hand, he seems eager to go against the idea of unity, to break the rules of linearity, and to avoid repeating himself. Since authorial statements always have to be treated with caution - and certainly in the case of Monterroso - I will now turn to a more detailed analysis of one of Monterroso's texts themselves, namely Perpetual Motion, so as to see whether the author's metaphor of the book as a box can be said to apply at all.

\section{PERPETUAL MOTION: MORE THAN A BOX}

It is possible that the metaphor of the box is just another of Monterroso's tricks, as he is famous for his humour, irony and complexity. I will analyse Perpetual Motion by taking recourse to the theory of the short story cycle. According to James Nagel, 'a central point is that in the short-story cycle each component work must stand alone (with a beginning, middle and end) yet be enriched in the context of the interrelated stories' (2001: 15). This way of an enlarging or widening perception of the reader has also been examined by Robert Luscher:

While each short story probes a select and seemingly isolated episode in some depth from a particular standpoint, it may still be part of some 
larger conceptual whole, one indication of a wider truth or thematic current that a single short story cannot chart completely.

A detailed analysis of Perpetual Motion should allow us to determine if and how the texts are linked together so as to create a form of internal unity as well as a larger conceptual whole.

First, the recurring elements are the epigraphs about flies that introduce each story or essay. The fly is a powerful symbol in Monterroso's work in general, but especially in Perpetual Motion, where it represents either evil or movement (Van Hecke 2003a). In the first essay, 'Flies', Monterroso explains that years ago he had the intention to compile 'a world anthology of the fly' (1995: 81) and that these quotes offer just a small sample of this compilation. Monterroso never completed that book, but the quotes he reproduces at the start of each text nevertheless serve to create a kind of book within the book. Some quotes are from philosophical texts, as the one by Ludwig Wittgenstein: 'What does one propose with philosophy? To teach the fly how to escape from the bottle' (Monterroso 1995: 93). But most are poems or extracts from poems, such as this one by W. B. Yeats: 'Once a fly dancing ... Could fill your heart with dreams none other knew ...' (Monterroso 1995: 116). Because Monterroso's texts themselves are mostly short stories and essays, these epigraphs also cause a kind of generic tension. Sometimes the epigraph thematically announces the text that follows, as in traditional epigraphs, but most often such a thematic link is missing. As a result, the quotes primarily seem to serve another purpose, namely that of overtly connecting the texts to one another, creating the semblance of unity. Clearly, the omnipresence of the fly in Perpetual Motion contributes to the unity of the book.

Second, the last text of Perpetual Motion reveals a particular view on the book as a whole. It carries the title, 'Fe de erratas y advertencia final'/'Errata and Final Notice' and begins as follows: 'The book ends on this page, number 152, which does not mean it could not also begin again here in a backward motion as useless and irrational as the one undertaken by the reader to reach this point' (Monterroso 1995: 152). In this way, the author can be seen to explicitly create a circular movement. While it may be 'useless and irrational', you can indeed read the book from the beginning to the end and, as the author suggests, then start all over again, reading backwards from the last text up to the first. By suggesting these movements, in both directions, Monterroso again clearly constructs the book as a whole, with a twofold linearity that links all the texts. Furthermore, this fragment can be seen as tribute to Julio Cortázar, who did something similar in his novel Rayuelal Hopscotch (1963). Cortázar himself proposes an alternative reading strategy for the novel by giving a list of the chapters in an - apparently - haphazard way ([1963] 1986: 111). By following this alternative order, the reader gets a completely different story. In Perpetual Motion the reader can similarly follow Monterroso's advice and read backwards. In that case, the last text is 'Flies'. In short, the fly will always be there, either at the beginning or at the end. This potentially endless movement back and forth is also referred to by the title of the book: perpetual motion.

Another way to explain this two-way reading of the book is by reference to Monterroso's fascination for palindromes: words or phrases that read the same, backward and forward. The essay, 'Onís es asesino', ${ }^{4}$ which can be found in the middle of Perpetual Motion, is even entirely devoted to the subject of

\footnotetext{
4. The literal translation is 'Onis is a murderer', but of course the phrase is primarily interesting as a palindrome.
} 
palindromes (Monterroso 1999: 81), such as the famous 'Madam I'm Adam'. This article has been omitted from the English translation, quite without explanation from the editor or the translator. This is probably due to the fact that the essay is perceived as untranslatable because of the wordplays. Still, the essay is important in terms of the structure of the book: it functions like a mirror and embodies, at a micro-level, the structure of the book as a whole. Clearly, Monterroso's structure is far less random or disordered than his metaphor of the box or container suggests. Indeed, the book as a whole has a palindromic structure, which is prefigured in the central essay of the book.

A third element of unity concerns the main character. Critics have argued that a recurring character is one of the main methods of creating unity in a short story cycle. In Perpetual Motion, such a recurring character is the writer or narrator. In omnisciently narrated stories, he is called 'the writer', as in the stories 'It's All the Same' (Monterroso 1995: 90), 'Regarding Attributions' (1995: 91) or 'Homo scriptor' (Monterroso 1995: 112). In other texts, he stages real writers, as in 'The Brain Drain' (Monterroso 1995: 96) or 'The Advantages and Disadvantages of Jorge Luis Borges' (Monterroso 1995: 105). Finally, the writer also often appears as the first-person narrator, as in 'Flies' (Monterroso 1995: 81) or in 'How I Got Rid of Five Hundred Books' (Monterroso 1995: 117). In all of these stories, the writer talks about his work, his anxieties, his struggles, his visions on literature. This 'writer' is not necessarily identical to Monterrroso as a real person. It is more an abstraction which stages what Monterroso considers the work of 'the writer'.

The fourth argument that supports the perception of the book as a whole is situated on a thematic level. The theme of perpetual movement is of course announced in the title of the book, which is also the title of one of the stories. The dichotomy between movement and immobility is strongly present in Perpetual Motion, as I have examined in an earlier article on the importance of Heraclitus and Zeno in Monterroso's work (Van Hecke 2003b). Heraclitus is known for his aphorism 'everything flows' and Zeno of Elea is known for his paradoxes, especially about immobility. Another recurrent topic that links the texts together is brevity. In his analysis of Perpetual Motion, José Miguel Oviedo focuses on those texts that stage this idea of brevity, short stories as well as essays. The story 'It May Be True', for instance, refers to an author who cannot write anymore because of his success, as he 'cannot write anything without offending someone [he] know[s]' (Monterroso 1995: 137). The figure of the writer suffering from writer's block, which was an anxiety shared by Monterroso, recurs in the story 'Tender Rose' (1995: 148). About the story 'Fecundity', further, Oviedo argues that Monterroso 'achieves the apotheosis of irony by reducing everything to a simple phrase' (Oviedo in Monterroso [1972] 1999: 12-13, Prologue): 'Today I feel well, like a Balzac; I am finishing this line' (Monterroso 1995: 109). Finally, in the essay 'Brevity', as we have seen above, the short story writer expresses the desire to write 'long texts, interminably long texts'. 'Brevity', which starts with a reference to the Satires of Horace, ends with the writer's acceptance of something stronger than himself. It is as if Monterroso humbly accepts the role of the poet as mediator between gods and men: he can only write short texts because the period has been 'imposed' upon him by some strange force (1995: Eng. 151). Brevity appears at all levels in the book Perpetual Motion: Monterroso's style is characterized by conciseness: his sentences are usually short, the texts are all short, and, as we have seen, brevity is an important theme in some short stories and essays as well. This creates an interesting interaction between the short stories

1. 2. 3. 4. 5. 6. 7. 8. 9. 10. 11. 12. 13. 14. 15. 16. 17. 18. 19. 20. 21. 22. 23. 24. 25. 26. 27. 28. 29. 30. 31. 32. 33. 34. 35. 36. 37. 38. 39. 40. 41. 42. 43. 44. 45. 46. 47. 48. 49. 50. 51. 52. 
and the essays on brevity, which again corroborates the vision we have of the book as a whole.

A fifth element of coherence can be found in the intertextual dimension that characterizes all texts. Monterroso has often claimed to be more of a reader than a writer ([1981] 1989: 20) and his readings constantly figure, explicitly or implicitly, in his essays and stories. The references to other authors create links that at first sight may seem chaotic, but that can have a profound logic or reveal surprising facts about some literary works. Let us consider just one example: Cervantes is referred to in six of the 32 texts. ${ }^{5}$ Some of these references are comical, as in the next dialogue:

Have you read Paradiso [by Lezama Lima]? I couldn't. You haven't finished one thing when the next one appears. You've read it? No, you say jokingly, I'm still getting through Don Quixote, knowing full well you've never read Don Quixote, that it bores you to death as the great Lope de Vega said about Dante on his deathbed.

(Monterroso 1995: 135)

Other comments are more serious: 'And no one today believes that the author of Avellaneda's Don Quixote is anyone other than Cervantes' (Monterroso 1995: 92). All these references, comical or not, reveal how important Cervantes is for Monterroso. He knows most people have not read Don Quixote, even if they pretend to have read it, yet his references are intended to direct the reader anew to Cervantes and his book, in the same way as Monterroso rediscovered Cervantes through Borges: 'Following him [Borges] meant discovering and descending to new circles: Chesterton, Melville, Bloy, Swedenborg, Joyce, Faulkner, Woolf; it meant renewing old relationships: Cervantes, Quevedo, Hernández' (1995: 105). In short, these and other intertextual references in Perpetual Motion bring the stories together and reinforce the perception of a recurrent pattern.

\section{CONCLUSION}

Although the previous arguments have shown different aspects of unity in Perpetual Motion, the question remains whether we can consider this book a short story collection or short story sequence. In spite of all the elements of unity and linkage that Perpetual Motion displays, the book is also marked by heterogeneity. Unlike a typical short story cycle, it contains not just short stories, but a mixture of short stories and essays and in some instances, it is hard to tell them apart. Moreover, as Forrest Ingram has argued, it is important to take authorial statements into account. In the case of Monterroso, as we have seen, these seem to emphasize heterogeneity over unity and coherence. However, when reading his comments on his books, you never know whether he is trying to put you on the wrong track.

In all, I would argue that both interpretations of Perpetual Motion are valid. On the one hand, it is perfectly acceptable to see the book as a simple box, as a collection, and to read each text as an autonomous story or essay. On the other hand, there are also recurrent elements in the book which invite a reading in terms of a more unified short story cycle. When taking this perspective, the reader is likely to achieve a more complex and more varied view on the recurrent protagonist of the writer, the frequent themes of brevity and perpetual motion,

\author{
5. These results can be \\ deduced from the \\ study on intertextual \\ references in \\ Monterroso's whole \\ work (Van Hecke 2005: \\ 387-477, 'Indices'). The \\ authors that are most \\ often mentioned in \\ Perpetual Motion are \\ Cervantes (6), Cortázar \\ (3), Dante (3), Darío (4) \\ Joyce (5), Neruda (4), \\ Reyes (3), Shakespeare \\ (3) and Swift (3)
}


and the intertextual network evoked by the book. The concept of 'unique hybrids' proposed by Luscher expresses well this twofold dimension of Perpetual Motion:

These works should be viewed, not as failed novels, but as unique hybrids that combine two distinct reading pleasures: the patterned closure of individual stories and the discovery of larger unifying strategies that transcend the apparent gaps between stories.

(Luscher 1989: 150)

Both perceptions can be linked to a visual image offered by the Colombian writer Juan Gabriel Vásquez. Vásquez likens short story collections to the art of painting:

A good short story collection [...] is not a succession of panels like The Garden by Bosch, but a series like Las Meninas by Picasso, where the sum of the different parts is more than the whole, but in which there is nothing too much.

1. 2. 3. 4. 5. 6. 7. 8. 9. 10. 11. 12. 13. 14. 15. 16. 17. (Vásquez 2009: 81) 18.

In my opinion, moreover, both perceptions can be seen to complement each other. Perpetual Motion, in fact, can be seen both as The Garden by Bosch, or as Las Meninas by Picasso. The textual diversity both of Monterroso's work in general and of Perpetual Motion in particular is then not a problem to be solved but an integral aspect of the short story collection. Its unity is taken into serious consideration by Monterroso, both with regard to his own work and that of others. Yet, unity is not a goal he seeks to achieve. It is, rather, a concept that he is often uncomfortable with and that he struggles with throughout his oeuvre. The fluidity and hybridity of texts such as Perpetual Motion can thus be seen as a manifestation of a deep-seated conflict within a writer who recognizes our desire for unity, yet nevertheless always veers towards fragmentation, rupture and disintegration.

\section{REFERENCES}

Anderson Imbert, E. (1979), Teoría y técnica del cuento, Barcelona: Ariel.

Antonaya Núñez-Castelo, M. L. (2000), 'El ciclo de cuentos como género narrativo en la literatura española', Rilce, 16: 3, pp. 433-78.

Audet, R. (2000), Des textes à l'auvre. La lecture du recueil de nouvelles, Editions Nota Bene.

Brescia, P. and Romano, E. (eds) (2006), El ojo en el caleidoscopio , México: UNAM.

Cortázar, Julio ([1962] 1990), Historias de cronopios y de famas, México: Alfaguara.

_- ([1963] 1986), Rayuela, Madrid: Cátedra.

_ (1969), Cronopios and Famas (trans. P. Blackburn), New York: Pantheon Books.

(1991), Hopscotch, New York: Pantheon Books.

De Mora, C. (1995), En breve: Estudios sobre el cuento hispanoamericano contemporáneo, Sevilla: Universidad de Sevilla.

Fresán, R. (2002), 'El extranjero. The Whore's Child and Other Stories, Richard Russo', http://www.pagina12.com.ar/diario/suplementos/libros/ 7-211-2002-07-28.html. Accessed 12 October 2013.
20.

21.

22.

23.

24.

25.

26.

27.

28.

29.

30.

31.

32.

33.

34.

35.

36.

37.

38.

39.

40.

41.

42.

43.

44.

45.

46.

47.

48.

49.

50.

51.

52. 
Goloboff, G. M. (1983), 'Augusto Monterroso', Caravelle, 40: 2, pp. 186-88.

Johnson, B. S. (1999), The Unfortunates, London: Picador.

Luscher, R. M. (1989), 'The short story sequence: An open book', in S. Lohafer and J. E. Clarey (eds), Short Story Theory at a Crossroads, Baton Rouge: Louisiana State University Press, pp. 148-67.

Menton, S. (1979), El cuento hispanoamericano. Antología crítico-histórica, México: FCE.

Mercado Rodríguez, S. (2012), 'Hibridación y experimentación genérica en la narrativa puertorriqueña reciente', unpublished paper presented at the conference El canon en la prosa contemporánea del Caribe hispano y del Cono Sur, University of Antwerp, 22-24 November.

Monterroso, Augusto ([1959] 1990), Obras completas (y otros cuentos), México: Ediciones Era.

_ ([1969] 1991), La Oveja Negra y demás fábulas, Barcelona: Anagrama. - ([1971] 2005), The Black Sheep and Other Fables (trans. R. D. V. Glasgow and P. Jenkins), London: Acorn.

__ ([1972] 1999), Movimiento Perpetuo, Madrid: Alfaguara Bolsillo. - ([1978] 1986), Lo demás es silencio, Madrid: Cátedra.

- ([1981] 1989), Viaje al centro de la fábula, México: Ediciones Era.

- ([1983] 1985), La palabra mágica, Barcelona: Muchnik Editores.

- ([1987] 1998a), La letra e (Fragmentos de un diario), Madrid: Alfaguara.

- (1995), Complete Works and Other Stories (trans. E. Grossman), Austin: University of Texas Press.

(1998b), La vaca, Madrid: Alfaguara.

- (2004), Literatura y vida, Madrid: Alfaguara.

Monterroso, A. and Jacobs, B. (eds.) (1997), Antología del cuento triste, México: Alfaguara.

Nagel, J. (2001), The Contemporary American Short Story Cycle. The Ethnic Resonance of Genre, Baton Rouge: Louisiana State University Press, pp. 1-17.

Pupo-Walker, E. (1995), El cuento hispanoamericano ante la crítica, Madrid: Castalia.

Van Hecke, A. (2003a), 'La mosca de Monterroso', Quimera, 230 (May), pp. 29-34.

— (2003b), 'Movimiento e inmovilidad: Heráclito y Zenón en Monterroso', Exemplaria, Revista de literatura comparada, 7, pp. 9-50.

_ (2005), 'Espacio e intertextualidad en Augusto Monterroso. Un viaje de Guatemala a México', doctoral dissertation, University of Antwerp.

Vásquez, J. G. (2009), 'Apología de las tortugas', El arte de la distorsión, Bogotá: Alfaguara.

\section{SUGGESTED CITATION}

Hecke, A. V. (2013), 'Augusto Monterroso's short story collections: More than stories in a box, Short Fiction in Theory \& Practice 3: 2, pp. 235-246, doi: 10.1386/fict.3.2.235_1

\section{CONTRIBUTOR DETAILS}

An Van Hecke studied Romance Philology at the KU Leuven. She obtained a Master's degree at the UNAM in Latin American Studies and a Ph.D. in Literature at the University of Antwerp with a dissertation on Augusto Monterroso. She is a lecturer of Spanish and coordinator of the Master in 
Translation at the Faculty of Arts, KU Leuven, campus Antwerp. She has 1. published articles on Mexican, Chicano and Guatemalan literature. Her main areas of research are intercultural relations, national identity, intertextuality, bilingualism and (self) translation. Her book, Monterroso en sus tierras: espacio e intertexto (2010) has been published by the Editorial de la Universidad Veracruzana.

Contact: Faculteit Letteren, KU Leuven, campus Antwerpen, Sint-Andriesstraat 2, 2000 Antwerpen, Belgium.

E-mail: an.vanhecke@arts.kuleuven.be

An Van Hecke has asserted her right under the Copyright, Designs and Patents Act, 1988, to be identified as the author of this work in the format that was submitted to Intellect Ltd. 